\title{
EVALUATION OF BIOLOGICAL ACTIVITIES OF ACETONE EXTRACT OF THE MUSHROOM LECCINUM SCABRUM
}

\author{
JOVANA TUBIĆ VUKAJLOVIĆ ${ }^{1}$, MARIJANA KOSANIĆ ${ }^{1}$, BRANISLAV RANKOVIĆ ${ }^{1}$, \\ TATJANA STANOJKOVIĆ ${ }^{2}$, ALEKSANDRA MARKOVIĆ ${ }^{1}$, DARKO GRUJIČIĆ ${ }^{1}$, NINOSLAV \\ DJELIĆ $^{3}$, MILENA RADAKOVIĆ ${ }^{3}$, OLIVERA MILOŠEVIĆ-DJORDJEVIĆ ${ }^{1,4 *}$ \\ ${ }^{I}$ University of Kragujevac, Faculty of Science, Department of Biology and Ecology, 34000 Kragujevac, Serbia \\ ${ }^{2}$ Institute of Oncology and Radiology of Serbia, 11000 Belgrade, Serbia \\ ${ }^{3}$ University of Belgrade, Faculty of Veterinary Medicine, 11000 Belgrade, Serbia \\ ${ }^{4}$ University of Kragujevac, Faculty of Medical Sciences, Department of Genetics, 34000 Kragujevac, Serbia
}

*corresponding author: olivera.djordjevic@pmf.kg.ac.rs

Manuscript received: November 2020

\begin{abstract}
Bioactivity of acetone extract of Leccinum scabrum was evaluated. Antioxidant activity was evaluated by free radical scavenging activity, reducing power and determination of total phenolic content. The microdilution plate method was used to detect antimicrobial activity. Cytotoxic activity was tested by MTT assay. Genotoxic potential was evaluated by comet assay. Results showed a stronger free radical scavenging activity, but the reducing power was less pronounced. The total content of phenols in the extract was $14.91 \mu \mathrm{g} \mathrm{PE} / \mathrm{mg}$. The minimum inhibitory concentration related to the tested microorganisms fluctuated in the range $0.039-10 \mathrm{mg} / \mathrm{mL}$. The most sensitive was Bacillus cereus. A strong cytotoxic activity was revealed with $\mathrm{IC}_{50}$ values ranging between 73.64 and $200.00 \mu \mathrm{g} / \mathrm{mL}$, among which HeLa was the most sensitive. Results showed that the extract was not genotoxic and it decreased the $\mathrm{H}_{2} \mathrm{O}_{2}$-induced GDI values in comparison to the positive control. $L$. scabrum possesses bioactivities such as antioxidant, antimicrobial, cytotoxic, no genotoxic and protective against $\mathrm{H}_{2} \mathrm{O}_{2}$, and in the highest tested concentration it showed a synergistic activity.
\end{abstract}

\section{Rezumat}

Studiul prezintă evaluarea activităţii biologice a extractului în acetonă obținut din Leccinum scabrum. Activitatea antioxidantă a fost evaluată prin determinarea capacității de chelatare a radicalilor liberi, a capacității reducătoare și a conținutului total în fenoli. Activitatea antimicrobiană a fost testată prin metoda microdiluției, activitatea citotoxică prin metoda MTT, iar potențialul genotoxic a fost determinat prin calcularea indexului de deteriorare genetică. Conținutul total de fenoli a fost $14,91 \mu \mathrm{g} P \mathrm{PE} / \mathrm{mg}$. Concentrația minimă inhibitorie a variat în intervalul $0,039-10 \mathrm{mg} / \mathrm{mL}$. Activitatea citotoxică pronunțată a fost corelată cu valorile $\mathrm{IC}_{50}$ în domeniul $73,64-200,00 \mu \mathrm{g} / \mathrm{mL}$. Rezultatele au arătat că extractul nu este genotoxic şi au scăzut valorile indexului de deteriorare genetică-indus de $\mathrm{H}_{2} \mathrm{O}_{2}$, în comparație cu controlul pozitiv. $L$. scabrum posedă activități antioxidantă, antimicrobiană, citotoxică ș1 protectoare împotriva $\mathrm{H}_{2} \mathrm{O}_{2}$.

Keywords: biological activities, mushroom Leccinum scabrum, acetone extract

\section{Introduction}

Edible mushrooms are nutritionally referred as functional food because of their beneficial components, including carbohydrates, proteins, vitamins and minerals, low levels of calories, fat and toxic metals $[1,2]$. Moreover, their primary (e.g., polysaccharides and glycoproteins) and secondary (e.g., phenolic compounds) bioactive compounds have remarkable medicinal functions such as antiviral, anti-inflammatory, immunoregulatory, antioxidant and antitumor activities [3-7]. Leccinum scabrum, also known as "birch boletus" is an edible mushroom belonging to the Boletaceae family [8]. This species is a popular, wild-grown mushroom, used traditionally as gourmet in Scandinavia and in Central and Eastern Europe [1]. L. scabrum is a good source of minerals ( $\mathrm{Mg}, \mathrm{K}, \mathrm{Na}, \mathrm{Ca}, \mathrm{Zn})$ and phenolic acids (syringic and gallic) [9]. The study by
Gąsecka et al. [10], based on chromatographic analysis revealed that $L$. scabrum is rich of flavonoids (catechin, kaempferol, apigenin and rutin) and phenolic acids ( $t$-cynnamic, protocatechuic, vanillic, 2,5-dihydroxybenzoic, 4-hydroxybenzoic, syringic, salicylic, caffeic, chlorogenic and ferulic acids), as well as vitamins (ascorbic acid and ergosterol). The results of this study showed that the analysed L. scabrum is a potential source of some health-promoting substances. Studies have confirmed that $L$. scabrum possesses antioxidant [10-12], antiulcer and cytotoxic activities [9].

Available literature contains very few data about the biological activities of this species. Thus, the aim of this study was to determine the biological (antioxidant, antimicrobial, cytotoxic and genotoxic) activities of the acetone extract from the mushroom L. scabrum. 


\section{Materials and Methods}

\section{Fungal materials}

Fungal samples of L. scabrum (Bull.) Gray were collected from Priboj, Serbia, in September 2017. The voucher sample is preserved in the facilities of the Department of Biology and Ecology of Kragujevac, Serbia, Faculty of Science. The determination of mushrooms was performed using standard methods [8]. Extraction

Dry finely ground thalli of the examined mushrooms were extracted using in a Soxhlet apparatus. The extract was filtered and then concentrated under reduced pressure in a rotary evaporator. The dry extract was stored at $-18^{\circ} \mathrm{C}$ until it was used in the tests. The extract was dissolved in phosphate buffer saline (PBS: $\mathrm{NaCl}, \mathrm{KH}_{2} \mathrm{PO}_{4}, \mathrm{Na}_{2} \mathrm{HPO}_{4} \times 2 \mathrm{H}_{2} \mathrm{O}, \mathrm{KCl}$ ) for the experiments.

Antioxidant activity

The antioxidant activity was evaluated by free radical (DPPH and superoxide anion radical) scavenging and reducing power. The free radical scavenging activity of the mushroom extract was measured by 1,1-diphenyl-2-picryl-hydrazil (DPPH) technique according to the Dorman et al.'s method [13]. The superoxide anion radical scavenging activity was detected according to the Nishimiki et al.'s method [14]. The Oyaizu method [15] was used to determine the reducing power. Total phenolic compounds in the mushroom extract were determined with Folin-Ciocalteu reagent according to the method of Slinkard and Singleton [16] using pyrocatechol as a standard phenolic compound.

\section{Antimicrobial activity}

The antimicrobial activity was evaluated against 10 microorganisms, including five strains of bacteria: Staphylococcus aureus (ATCC 25923), Bacillus subtilis (ATCC 6633), Bacillus cereus (ATCC 10987), Escherichia coli (ATCC 25922) and Proteus mirabilis (ATCC 12453) and five species of fungi: Aspergillus niger (ATCC 16888), Candida albicans (ATCC 10259), Penicillium italicum (ATCC 10454), Mucor mucedo (ATCC 20094), Trichoderma viride (ATCC 13233) obtained from the ATCC (American Type Culture Collection).

The bacteria isolates were picked from over-night cultures in Müller-Hinton agar and suspensions were prepared in sterile distilled water by adjusting the turbidity to match $0.5 \mathrm{McFarland}$ standards to approximately $10^{8} \mathrm{CFU} / \mathrm{mL}$. Fungal suspensions were prepared from 3- to 7-day-old cultures that grew on a potato dextrose agar except for $C$. albicans that was maintained on Sabouraud dextrose agar. The spores were rinsed with sterile distilled water, used to determine the turbidity spectrophotometrically at $530 \mathrm{~nm}$, and then further diluted to approximately $10^{6} \mathrm{CFU} / \mathrm{mL}$ according to the procedure recommended by NCCLS [17]. The 96-well micro-titre assay using resazurin as the indicator of cell growth [18] was employed for the determination of the minimum inhibitory concentration (MIC) of the active extract. Cytotoxic activity

Human epithelial carcinoma HeLa cells, human colon carcinoma LS174 cells, human lung carcinoma A549 and human lung fibroblast MRC-5 cells were obtained from the American Type Culture Collection (Manassas, VA, USA). All cancer cell lines were cultured as a monolayer in the RPMI 1640 nutrient medium, with $10 \%$ (inactivated at $56^{\circ} \mathrm{C}$ ) FBS, $3 \mathrm{mM}$ of Lglutamine, and antibiotics, at $37^{\circ} \mathrm{C}$ in humidified air atmosphere with $5 \% \mathrm{CO}_{2}$. The effect on cancer cell survival was determined $72 \mathrm{~h}$ after the addition of the extract, by the MTT assay [19].

Genotoxic potential

Lymphocytes were isolated from peripheral whole blood of healthy donors using Histopague-1077 (SigmaAndrich Co., United Kingdom) and subjected to the alkaline comet assay. Human peripheral blood was collected by venepuncture from healthy, non-smoking donors who had not been exposed to known mutagens. The study was conducted in accordance with the Declaration of Helsinki, and the protocol was approved by the Ethics Committee. The obtained lymphocytes were incubated for $30 \mathrm{~min}$ at $37^{\circ} \mathrm{C}$ in PBS solution with various concentrations of the Leccinum. scabrum mushroom acetone extract (50, 100, 150 and 200 $\mu \mathrm{g} / \mathrm{mL}$ ) separately and in treatment against the known mutagen, hydrogen peroxide $\left(\mathrm{H}_{2} \mathrm{O}_{2}\right)$.

Untreated lymphocytes were used as negative control, while lymphocytes treated with $\mathrm{H}_{2} \mathrm{O}_{2}$ alone (final concentration of $10 \mu \mathrm{g} / \mathrm{mL}$ ) were used as positive control. After the incubation, cell suspension was suspended in $1 \%$ low melting-point agarose (Sigma, St. Louis, MO) for embedding on slides. Slides were kept about 3 minutes on ice. After removing the coverslips, cells were lysed with freshly prepared lysis solution $(2.5 \mathrm{M} \mathrm{NaCl}, 100 \mathrm{mM}$ EDTA, $10 \mathrm{mM}$ Tris, $1 \%$ Triton $\mathrm{X}-100$ and $10 \%$ dimethyl sulfoxide, $\mathrm{pH} 10$ ) for $2 \mathrm{~h}$, in the dark, at $4^{\circ} \mathrm{C}$. Subsequently, alkaline denaturation was performed in an electrophoresis buffer solution (10 M NaOH, $200 \mathrm{mM}$ EDTA, $\mathrm{pH}>13$ ) and slides were electrophoresed for $30 \mathrm{~min}$ at $25 \mathrm{~V}$ and $300 \mathrm{~mA}$. Then, the slides were washed in neutralizing Tris- $\mathrm{HCl}$ buffer for $15 \mathrm{~min}(0.4 \mathrm{M}$ Tris, $\mathrm{pH}$ 7.5) and rinsed in distilled water. The slides were stained with ethidium bromide $(50 \mu \mathrm{g} / \mathrm{mL})$. Experiments were performed in dark to minimize the occurrence of additional DNA damage [20].

One hundred randomly selected cells from each slide were viewed under Nikon E50i fluorescent microscope at 400x magnification. Selected cells were analysed based on the criteria defined by Collins [21]: class 0 no damage; class 1 - low damage; class 2 - medium damage; class 3 - high damage and class 4 - total destruction. The Genetic Damage Index (GDI) for each sample was calculated using the following formula: 
FARMACIA, 2021, Vol. 69, 5

GDI $=($ Class $1+2 \times$ Class $2+3 \times$ Class $3+4 \times$ Class 4$) /$

$($ Class0 + Class $1+$ Class $2+$ Class $3+$ Class4 $)$.

Statistical analysis

The SPSS (version 20) software package was used for statistical analysis. The statistical analysis was performed by one-way analysis of variance (ANOVA). The comparisons between groups were made using Dunnett T3 post hoc test. Results are expressed as mean \pm standard deviation (SD). In all comparisons, $\mathrm{p}<0.05$ was considered as indicating statistical significance.

\section{Results and Discussion}

The free radical scavenging activity and reducing power of the tested extract are presented in Table I. The $\mathrm{IC}_{50}$ values were 52.16 and $14.90 \mu \mathrm{g} / \mathrm{mL}$ for DPPH radicals and superoxide anion radicals scavenging activity, respectively. As shown in Table I, the reducing power was concentration dependent. The measured values of absorbance for the reducing power varied from 0.0632 to 0.0199 . The total content of phenols in the extract was $14.91 \pm 0.92 \mu \mathrm{g}$ PE/mg (Table I).

Table I

Free radical scavenging activity, reducing power and phenolic content of the acetone extract of the edible mushroom Leccinum scabrum

\begin{tabular}{lcc}
\hline \multirow{2}{*}{ Tested mushroom } & DPPH radical scavenging activity \\
$\mathrm{IC}_{50}(\mu \mathrm{g} / \mathrm{mL})$
\end{tabular}

Presented results indicate that the acetone extract of $L$. scabrum showed very strong free radical scavenging activity, while the reducing power was less pronounced. This activity of the tested extract was based on the its ability to accelerate the formation of the nonradical form of DPPH-H as well as on its ability to destroy the superoxide radical produced from the phenazine methosulfate (PMS)/NADH reaction which is a weak oxidative agent but induces the formation of highly reactive free radicals.

In the literature there are several data regarding the antioxidant activity of $L$. scabrum [10-12]. It was determined the antioxidant activity for this species, but using other extraction solvents and high antioxidant activities were registered in all cases. In this study, the antioxidant activity of the mushrooms was confirmed by acetone extract. Different solvents, according to their polarity, may extract various compounds which results in a great antioxidant activity. This means that synergistic activities may occur between these constituents leading to the pronounced antioxidant activity of the mushroom extract (containing the antioxidant active components).

The antimicrobial activity of the mushrooms extract against the test microorganisms is shown in Table II.
Extract from L. scabrum acted on all tested microorganisms. The MIC fluctuated in the range 0.039 $0.156 \mathrm{mg} / \mathrm{mL}$ for bacteria and $5-10 \mathrm{mg} / \mathrm{mL}$ for fungi. The most sensitive, among the microorganisms, was B. cereus (MIC value $0.039 \mathrm{mg} / \mathrm{mL}$ ). The antimicrobial activity was compared with the standard antibiotics, streptomycin (for bacteria) and ketoconazole (for fungi). The results showed that the tested sample had similar antibacterial activity to streptomycin, while ketoconazole was more active than the tested mushroom extract. In the negative control, DMSO had no inhibitory activity on the tested organisms.

There is no available information about the antimicrobial potential of $L$. scabrum species, but some researchers have examined the antimicrobial potential of other related mushrooms. For example, Kosanić et al. [22] showed that acetone and methanol extracts from $L$. carpini exhibited antibacterial activity in lower concentrations $(1.25-10 \mathrm{mg} / \mathrm{mL})$ than our tested ones, while the antifungal activity was approximate as in our experiment. The intensity of the examined antimicrobial activity of $L$. scabrum depended on the tested microorganisms and the used concentration of extract. In this experiment, Gram negative bacteria were more resilient than Gram positive. This resistance 
FARMACIA, 2021, Vol. 69, 5

is likely due to the difference in the structure of the cell wall. Gram negative bacteria have a wall associated with an outer complex membrane, which slows down the passage of hydrophobic compounds. Gram positive bacteria are more susceptible to the antibiotic agents due to the absence of an outer membrane. Fungi were more resistant than bacteria due to the more complex structure of the cell wall [22].

Table II

Minimum inhibitory concentrations (MIC) of the acetone extract of Leccinum scabrum

\begin{tabular}{|c|c|c|c|}
\hline Bacteria and microfungi & Leccinum scabrum & Streptomycin & Ketoconazole \\
\hline \multicolumn{4}{|c|}{$\mathrm{MIC}(\mathrm{mg} / \mathrm{mL})$} \\
\hline Bacillus cereus & 0.039 & 0.019 & - \\
\hline Bacillus subtilis & 0.078 & 0.019 & - \\
\hline Escherichia coli & 0.156 & 0.039 & - \\
\hline Proteus mirabilis & 0.156 & 0.078 & - \\
\hline Staphylococcus aureus & 0.078 & 0.039 & - \\
\hline Aspergillus niger & 10 & - & 0.078 \\
\hline Candida albicans & 5 & - & 0.039 \\
\hline Mисог тисеdo & 5 & - & 0.156 \\
\hline Penicillium italicum & 5 & - & 0.156 \\
\hline Trichoderma viride & 5 & - & 0.078 \\
\hline
\end{tabular}

The cytotoxic activity of $L$. scabrum extract is shown in Table III. The $\mathrm{IC}_{50}$ against HeLa, LS174 and A549 cell lines were 73.64, 130.63 and $76.82 \mu \mathrm{g} / \mathrm{mL}$ respectively. As shown in Table III, the tested mushroom extract showed a weaker activity compared to cisDDP as a positive control. The extract expressed relatively strong cytotoxic activity on the used cancer cells, among which HeLa cells were the most sensitive. Cytotoxic activities on normal cells were not detected, so it is important to emphasize that this mushroom acted selectively when it comes to its cytotoxic potential.
There is no available information about the cytotoxic potential of $L$. scabrum species, but some researchers have examined the cytotoxic potential of other related mushrooms. For example, Kosanić et al. [23] showed that methanolic extracts from Agaricus campestris and Boletus edulis exhibited significant cytotoxic activities. Also, it has been proven that other edible mushrooms possess anticancer activities [24, 25]. Further research will be necessary in order to identify compounds responsible for the observed antitumor activities.

Growth inhibitory activity of Leccinum scabrum on HeLa, LS174, A549 and MRC5 cell survival

\begin{tabular}{ccccc}
\hline Cell lines & HeLa & LS174 & A549 & MRC-5 \\
\hline Tested mushroom & \multicolumn{5}{c}{$\mathrm{IC}_{50}(\mu \mathrm{g} / \mathrm{mL})$} \\
\hline Leccinum scabrum & $73.64 \pm 1.35$ & $130.63 \pm 1.85$ & $76.82 \pm 0.49$ & $<200$ \\
cis-DDP & $2.36 \pm 0.28$ & $20.38 \pm 0.44$ & $17.93 \pm 0.88$ & $10.52 \pm 0.22$ \\
\hline IC & \multicolumn{4}{c}{ values are expressed as the mean \pm SD determined from the results of MTT assay in two independent experiments }
\end{tabular}

Table IV

Protective activity of acetone extracts of Leccinum scabrum against $\mathrm{H}_{2} \mathrm{O}_{2}$ in cultured human lymphocytes using

\begin{tabular}{|c|c|c|c|c|c|c|c|}
\hline \multirow{2}{*}{ Treatment $(\mu \mathrm{g} / \mathrm{mL})$} & \multirow{2}{*}{$\begin{array}{c}\text { No. of analysed } \\
\text { cells }\end{array}$} & \multicolumn{5}{|c|}{ Classes of damage degree in cells } & \multirow{2}{*}{$\begin{array}{c}\text { GDI } \\
(\text { mean } \pm \mathrm{SD})\end{array}$} \\
\hline & & 0 & 1 & 2 & 3 & 4 & \\
\hline Negative control & 300 & 85.67 & 9.33 & 4.00 & 0.33 & 0.67 & $0.21 \pm 0.04$ \\
\hline Positive control & 300 & I & I & 7.00 & 41.33 & 51.67 & $3.45 \pm 0.10$ \\
\hline \multicolumn{8}{|l|}{ Separate treatment } \\
\hline 50 & 300 & 76.33 & 8.67 & 7.33 & 5.67 & 2.00 & $0.48 \pm 0.09$ \\
\hline 100 & 300 & 64.33 & 10.00 & 12.00 & 8.67 & 5.00 & $0.80 \pm 0.13$ \\
\hline 150 & 300 & 37.00 & 13.33 & 17.33 & 15.00 & 17.33 & $1.62 \pm 0.43$ \\
\hline 200 & 300 & 30.00 & 16.33 & 16.33 & 19.00 & 18.33 & $1.79 \pm 0.64$ \\
\hline \multicolumn{8}{|c|}{ Treatment against $\mathrm{H}_{2} \mathrm{O}_{2}$} \\
\hline $50+\mathrm{H}_{2} \mathrm{O}_{2}$ & 300 & 17.33 & 11.00 & 17.33 & 21.00 & 33.33 & $2.42 \pm 0.16^{*}$ \\
\hline $100+\mathrm{H}_{2} \mathrm{O}_{2}$ & 300 & 20.67 & 18.00 & 18.00 & 20.33 & 23.00 & $2.07 \pm 0.23^{*}$ \\
\hline $150+\mathrm{H}_{2} \mathrm{O}_{2}$ & 300 & 19.67 & 23.33 & 11.33 & 19.00 & 26.67 & $2.09 \pm 0.45$ \\
\hline $200+\mathrm{H}_{2} \mathrm{O}_{2}$ & 300 & 7.00 & 19.67 & 15.00 & 24.00 & 34.67 & $2.60 \pm 0.29$ \\
\hline
\end{tabular}

statistically significant difference in comparison to positive control (ANOVA, ${ }^{*} \mathrm{p}<0.05$ )

The results of the genotoxic potential are shown in Table IV. All tested concentrations of extract caused no significant increase of the GDI values (from $0.48 \pm$ 0.09 to $1.79 \pm 0.64$ ) compared to the negative control
$(0.21 \pm 0.04)$, which clearly shows that the extract was not genotoxic. Having determined that the mushroom itself did not induce DNA damage, the next step was to determine how it works against the 
$\mathrm{H}_{2} \mathrm{O}_{2}$ toxic effect. $\mathrm{H}_{2} \mathrm{O}_{2}$ is a known mutagen used as a positive control, which induced a significant increase in the number of cells with tail (comets) compared to the negative control $(\mathrm{p}<0.001)$. The extract decreased the $\mathrm{H}_{2} \mathrm{O}_{2}$ induced GDI values ( $\mathrm{p}<$ 0.05 ) in all tested concentrations but significantly in concentrations of $50(2.42 \pm 0.16)$ and $100 \mu \mathrm{g} / \mathrm{mL}$ $(2.07 \pm 0.23)$ in comparison to the positive control $(3.45 \pm 0.10)$. Thus, our results suggest that the extract showed clear protective activity against $\mathrm{H}_{2} \mathrm{O}_{2}$ in lower concentrations, while at the highest tested concentration it showed synergistic activity.

Similarly, previous studies have reported that related mushrooms did not produce genotoxic activity on human lymphocytes in vitro [26-28]. Also, Park et al. [29] and Živković et al. [28] have showed that extracts of Inonotus obliquus and Agaricus blazei offer protection against $\mathrm{H}_{2} \mathrm{O}_{2}$ induced DNA damage in healthy human lymphocytes at levels similar to those provided by other known antioxidants (ascorbic acid, trolox, $\alpha$ tocopherol). Ascorbic acid displayed a decrease of over $50 \%$ in the level of DNA damage in human lymphocytes [29]. However, Vickers [30] has shown that the combination of different compounds of a mushroom extract with the mutagen agents may have synergistic activity, which reinforces the influence of both individual factors. For these reasons, there is an increasing need to investigate the effects of mushroom extracts not only on healthy, but also on cells that have previously been exposed to mutagenicity.

\section{Conclusions}

The present study has shown that the mushroom $L$. scabrum has antioxidant and antimicrobial effects, but also a good cytotoxic and protective activity. It can be used as a good source of natural antioxidants and for pharmaceutical purposes in the prevention and treatment of various diseases.

\section{Acknowledgement}

This work was supported by the Serbian Ministry of Education, Science and Technological Development (Agreement No. 451-03-68/2020-14/200122).

\section{Conflict of interest}

The authors declare no conflict of interest.

\section{References}

1. Wang XM, Zhang J, Wu LH, Zhao YL, Li T, Li JQ, Wang YZ, Liu HG, A mini-review of chemical composition and nutritional value of edible wild-grown mushroom from China. Food Chem., 2014; 151: 279-285.

2. Gürgen A, Yildiz S, Can Z, Tabbouche S, Kiliç AO, Antioxidant, antimicrobial and anti-quorum sensing activities of some wild and cultivated mushroom species collected from Trabzon, Turkey. Fresen Environ Bull., 2018; 27(6): 4120-4131.

3. Devi KSP, Maiti KT, Immunomodulatory and anticancer properties of pharmacologically relevant mushroom glycans. Recent Pat Biotechnol., 2016; 10(1): $72-78$

4. Nguyen TK, Im KH, Choi J, Shin PG, Lee TS, Evaluation of antioxidant, anti-cholinesterase, and antiinflammatory effects of culinary mushroom Pleurotus pulmonarius. Mycobiology, 2016; 44(4): 291- 301.

5. Bal C, Akgul H, Sevindik M, Akata I, Yumrutas O, Determination of the anti-oxidative activities of six mushrooms. Fresen Environ Bull., 2017; 26(10): 6246-6252.

6. Yin C, Fan X, Fan Z, Shi D, Gao H, Effects of various treatments on extraction of the main bioactive components and determination of biological activity of extracts from the caterpillar medicinal mushroom Cordyceps militaris (Ascomycetes). Int J Med Mushrooms, 2018; 20(9): 873-885.

7. Sevendik M, Krupodorova T, Antioxidant potential and some mineral contents of wild edible mushroom Ramaria stricta. AgroLife Sci J., 2020; 9(1): 186-191.

8. Uzelac B, Fungi of Serbia and the Western Balkans, BGV, Logik, Belgrade, 2009.

9. Kała K, Krakowska A, Sułkowska-Ziaja K, Szewczyk A, Reczyński W, Opoka W, Muszyńska B, Kinetics of extracted bioactive components from mushrooms in artificial digestive juices. Int J Food Prop., 2017; 20(8): 1796-1817.

10. Gąsecka M, Siwulski M, Mleczek M, Evaluation of bioactive compounds content and antioxidant properties of soil-growing and wood-growing edible mushrooms. J Food Process Pres., 2017; 42(1): 1-10.

11. Keleş A, Koca I, Genccelep H, Antioxidant properties of wild edible mushrooms. J Food Process Technol., 2011; 2(6): 130: 1-6.

12. Witkowska AM, Zujko ME, Mironczuk-Chodakowska I, Comparative study of wild edible mushrooms as sources of antioxidant. Int J Med Mushrooms, 2011; 13(4): 335-341.

13. Dorman HJ, Bachmayer O, Kosar M, Hiltunen R, Antioxidant properties of aqueous extracts from selected Lamiaceae species grown in Turkey. J Agric Food Chem., 2004; 52(4): 762-770.

14. Nishimiki M, Rao NA, Yagi K, The occurrence of super-oxide anion in the reaction of reduced phenazine methosulfate and molecular oxygen. Biochem Bioph Res Co., 1972; 46(2): 849-853.

15. Oyaizu M, Studies on products of browning reaction antioxidative activities of products of browning reaction. Prepared from glucosamine. Jpn J Nutr., 1986; 44(6): 307-314.

16. Slinkard K, Slingleton VL, Total phenol analyses: automation and comparison with manual methods. Am J Enol Vitic., 1997; 28: 49-55.

17. NCCLS (National Committee for Clinical Laboratory Standards), Reference method for broth dilution antifungal susceptibility testing of conidia-forming filamentous fungi, Proposed Standard M38-P. Wayne, USA, 1998.

18. Sarker SD, Nahar L, Kumarasamy Y, Microtitre platebased antibacterial assay incorporating resazurin as an 
indicator of cell growth, and its application in the in vitro antibacterial screening of phytochemicals. Methods, 2007; 42(4): 321-324.

19. Mosmann T, Rapid colorimetric assay for cellular growth and survival: application to proliferation and cytotoxicity assays. J Immunol Methods, 1983; 65(1-2): 55-63.

20. Singh NP, McCoy MT, Tice RR, Schneider EL, A simple technique for quantitation of low levels of DNA damage in individual cells. Exp Cell Res., 1988; 175(1): 184-191.

21. Collins AR, The comet assay for DNA damage and repair: principles, applications, and limitations. Molec Biotechnol., 2004; 26(3): 249-261.

22. Kosanić M, Ranković B, Dasić M, Mushrooms as possible antioxidant and antimicrobial agents. Iran J Pharm Res., 2012; 11(4): 1095-1102.

23. Kosanić M, Ranković B, Rančić A, Stanojković T, Evaluation of metal concentration and antioxidant, antimicrobial, and anticancer potentials of two edible mushrooms Lactarius deliciosus and Macrolepiota procera. J Food Drug Anal., 2016; 24(3): 477-484.

24. Patel S, Goyal A, Recent developments in mushrooms as anti-cancer therapeutics: a review. 3 Biotech, 2012; 2(1): 1-15.

25. Maheshwari R, Chauhan V, Health Benefits of Edible Mushrooms. Bull Environ Pharmacol. Life Sci., 2012; 1(9): 92-93.
26. De Oliveira JM, Jordão BQ, Ribeiro LR, da Eira $\mathrm{AF}$, Mantovani MS, Anti-genotoxic effect of aqueous extracts of sun mushroom (Agaricus blazei Murill lineage 99/26) in mammalian cells in vitro. Food Chem Toxicol., 2002; 40(12): 1775-1780.

27. Radaković M, Djelić N, Stevanović J, Soković M, Radović D, Van Griensven LJ, Evaluation of the antigenotoxic effects of the Royal Sun mushroom, Agaricus brasiliensis (higher Basidiomycetes) in human lymphocytes treated with thymol in the comet assay. Int J Med Mushrooms, 2015; 17(4): 321-330.

28. Živković L, Borozan S, Čabarkapa A, Topalović D, Ciptasari U, Bajić V. Spremo-Potparević B, Antigenotoxic properties of Agaricus blazei against hydrogen peroxide in human peripheral blood cells. Oxid Med Cell Longev., 2017; 2017: 8759764: 1-9.

29. Park JK, Lee HB, Jeon EJ, Jung HS, Kang MH, Chaga mushroom extract inhibits oxidative DNA damage in human lymphocytes as assessed by comet assay. Bio Factors, 2004; 21(1-4): 109-112.

30. Vickers A, Botanical medicines for the treatment of cancer: Rationale, overview of current data, and methodological considerations for phase I and II trials. Cancer Invest., 2002; 20(7-8): 1069-1079. 